\title{
STRATEGI MENINGKATKAN PENJUALAN KERIPIK DAN SALE PISANG AMALIA MELALUI DIGITAL MARKETING
}

\author{
Iwan Mulyana \\ mulyanaku@gmail.com \\ Duduh Sujana \\ duduhmesy@gmail.com \\ Rukanda Ahmad Sulanjana \\ rd.akhmadsl@gmail.com
}

SEKOLAH TINGGI ILMU EKONOMI EKUITAS

\begin{abstract}
ABSTRAK
Kabupaten Sumedang tumbuh dan mengalami perubahan yang cukup signifikan. Sebagai faktor pendorong perubahan tersebut tercermin dengan adanya sektor industri yang didominasi oleh industri mikro, kecil dan menengah yang salah satu diantaranya adalah pengusaha industri kecil sale dan kripik pisang Merek Amalia. Pengusaha ini berada di desa Citali RT1 RW1 Kecamatan Pamulihan Kabupaten Sumedang, dan merupakan peserta UMKM Jabar serta pernah menjadi Juara UMKM berkinerja baik pada tahun 2019. Tujuan kegiatan pengabdian ini untuk membantu memasarkan produk industri yang kondisinya belum bisa memasarkan produk secara digital marketing. Pelaksanaan pengabdian dimulai dengan memberikan penyuluhan, pelatihan pemasaran secara online (media sosial), pendampingan kepada owner agar setiap saat mampu berbisnis secara online dan toko yang offline serta memberikan bantuan berupa alat pengering (spinner) dan sealer dengan tujuan agar produk sale dan kripik bisa mempunyai waktu periode lama dan tidak cepat rusak. Melalui kegiatan pengabdian ini pemilik sale dan kripik pisang Amelia mampu melakukan proses produksi sale dan kripik lebih baik, tahan lama dan tidak cepat rusak, dan mampu memasarkan produknya lebih luas lagi melalui digital marketing.
\end{abstract}

Kata kunci: Industri, Pemasaran, Sale dan Kripik, UMKM.

\section{PENDAHULUAN}

Kabupaten Sumedang merupakan salah satu kabupaten yang berada di provinsi Jawa Barat yang terletak ditengah tengah provinsi yang menghubungkan kota dan kabupaten yang akan menuju ke ibu kota Jawa Barat yaitu kota Bandung. Dengan adanya hal tersebut, Kabupaten Sumedang menjadi tumbuh dan mengalami perubahan yang cukup signifikan. Salah satu faktor pendorong perubahan tersebut diantaranya yaitu dengan adanya sektor industri yang di dominasi oleh industri Mikro, kecil dan Menengah.

Potensi industri mikro dan industri kecil yang menjadi unggulan Kabupaten Sumedang terdiri dari industri senapan angin, industri meubeul kayu, industri anyaman bambu, industri wayang golek, industri tahu, industri opak ketan, industri 
ubi cilembu, industri sale dan kripik pisang dan masih banyak lagi. Namun, berbagai komoditas tersebut belum ada komoditas yang menembus pasar ekspor dan hanya menjadi primadona di pasar lokal. Hal ini memberi indikasi bahwa sektor ini masih perlu dikembangkan dan dioptimalkan, sehingga dapat menopang aktivitas perekonomian dan pembangunan (Suryana, 2020).

Seirama dengan program Pemerintah kabupaten Sumedang dalam rangka membantu dan meningkatkan usaha home industry khususnya di kalangan UMKM. Industri sale dan kripik pisang merupakan salah satu industi unggulan kabupaten Sumedang yang diantara pengusahanya yaitu pengusaha (UMKM) Kripik dan Sale pisang Amalia yang berlokasi di desa Citali RT1 RW1 Kecamatan Pamulihan Kabupaten Sumedang. Akses menuju lokasi ini dapat dijangkau baik dengan kendaraan roda dua, maupun dengan kendaraan roda empat. Usaha ini merupakan usaha UMKM sehingga tempat produksi cukup dikenal di Desa Citali Dan Telah Buka Toko Offline Di Daerah Tanjungsari Sumedang dan ada beberapa toko makanan di Bandung dan Tangerang menjadi pelangan tetap.

Pengusaha ini memulai usahanya yaitu sejak tahun 2010, berawal dari merebaknya usaha home industry yang memproduksi pisang nangka mentah menjadi kripik pisang yang banyak diminati oleh masyarakat, dan hal tersebut yang menjadikan motivasi untuk mencoba memulai usaha baru dan sekaligus dapat meningkatkan pendapatan serta dapat membantu kebutuhan keluarga disekitar Desa Citali Kecamatan Pamulihan. Masyarakat sekitar wilayah SELAI CAU Desa Citali pada umumnya relatif sudah mengenal usaha kripik pisang AMALIA, sehingga tidak perlu lagi mencari atau bertanya untuk sampai lokasi atau tempat produksi.

Bisnis kripik dan sale pisang merk dagang Amalia saat ini baru hanya memiliki izin PIRT dan HALAL, karena citra rasanya yang khusus dengan dukungan bahan baku pisang mentah yang melimpah, pada saat dilakukannya uji coba untuk di pasarkan di wilayah Sumedang dan Tanjungsari cukup banyak peminat sehingga atas hal tersebut pemilik terdorong untuk memperluas pangsa pasarnya melalui word of mouth, melalui WA dan dipasarkan langsung oleh salesman.

Namun, kondisi dilapangan dalam upaya untuk memenuhi permintaan pasar, pemilik mengalami beberapa kendala baik dari sisi permodalan yang masih tergantung pada penjualan dimana kondisi dilapangan proses pemasarannya masih belum begitu optimal juga terdapat permasalahan yang menyangkut produk dimana kripik dan sale pisang yang sudah digoreng kemudian ditiriskan sampai dianggap kering minyaknya kemudian dikemas, apabila produknya di simpan dalam waktu tertentu diantaranya banyak produk yang berjamur, sehingga hal tersebut sangat mempengaruhi sekali terhadap rasa dan kualitas produk, dan jika hal tersebut dibiarkan terus menerus (tidak terkontrol) akan sangat mempengaruhi terhadap penjualan karena banyak barang yang tidak terjual yang pada akhirnya menjadikan suatu kerugian yang sangat besar bagi perusahaan.

Berdasarkan kondisi dan situasi yang telah dijabarkan diatas, permasalahan prioritas dari masyarakat mitra adalah:

a. Promosi produk yang dilakukan selama ini, yaitu dengan cara menawarkan kepada setiap pedagang yang menjual produk kripik dan sale pisang, teman dekat dan lingkungan sekitar serta melalui selas untuk luar kota yang nampaknya masih kurang efektif sementara peluang pasar untuk produk keripik pisang Amalia ini sangat besar terutama di kota Bandung sebagai sasaran pemasarannya yang banyak didatangi turis lokal maupun asing terutama di hari libur atau weekend.

b. Peralatan yang digunakan untuk produksi masih skala untuk penggunaan kegiatan memasak sehari- hari misalnya alat penggorengan yang masih terbatas, penggorengan yang besar, mesin pemotong keripik dan mesin 
timbangan. Tambahan peralatan dibutuhkan terutama untuk memenuhi permintaan keripik pisang yang semakin meningkat dengan pasokan yang cukup besar.

c. Permasalahan atas produk yang kurang tahan lama sehingga berjamur hal tersebut disebabkan oleh kurang baiknya proses penirisan, yang nampaknya pada saat produk dikemas sisa minyak dari hasil penggorengan belum betul-betul kering sehingga menyebabkan produk jamuran.

d. Penggunaan tenaga kerja masih masyarakat sekitar rumah produksi dengan jumlah 2-5 orang sehingga perlu dilakukan analisis jabatan, pembentukan struktur organisasi dan sistem penggajian yang baik.

Dari permasalahan diatas, melalui program-program Pengabdian kepada Masyarakat ini dapat memberikan pengetahuan dan pelatihan mengenai cara memasarkan produk secara online kemudian membantu mitra untuk pengadaan alat pengering guna membantu proses penirisan supaya produk benar-benar kering pada saat dikemas sehingga menjadi tahan lama dan tidak mudah berjamur sehingga diharapkan kualitas produk tetap terjaga dan dapat meningkatkan penjualan serta meningkatkan pendapatan bagi mitra.

\section{METODE KEGIATAN}

Kegiatan pengabdian dilaksanakan di pengusaha (UMKM) Kripik dan Sale pisang Amalia yang berlokasi di Desa Citali RT1 RW1 Kecamatan Pamulihan Kabupaten Sumedang. Pelaksanaan kegiatan mulai dari penyuluhan sampai memberikan pelatihan digital marketing dilakukan sejak bulan Maret 2020.

Target pelatihan adalah kepada owner dan salesmen dengan tujuan agar pemahaman tentang digital dapat dipahami secara menyeluruh oleh unit-unit yang terlibat dari proses produksi sampai barang dipasarkan. Pelaksanaan kegiatan ini dilakukan dengan tahapan-tahapan sebagai berikut:

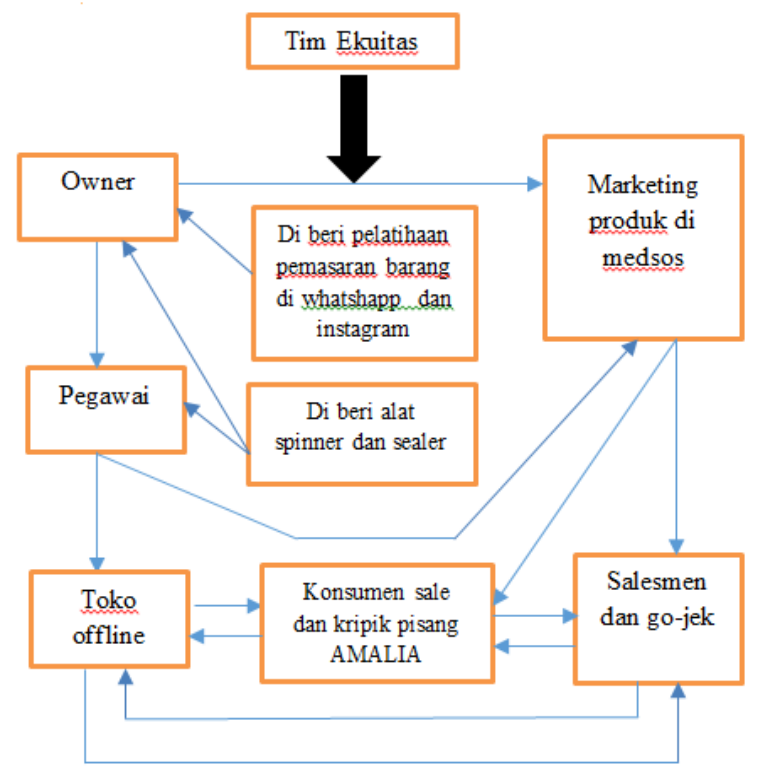

Gambar 1. Kerangka Pemecahan Masalah

Untuk mewujudkan solusi sebagaimana yang ditawarkan, maka beberapa langkah tahapan, perlu dilakukan. Tahapan-tahapan tersebut, meliputi tahapan persiapan dan pelaksanaan pelatihan (Murdjito, 2012). Penjelasan masing-masing tahapan, dapat dijelaskan sebagai berikut:

a. Tahap persiapan

Pada tahap ini, kegiatan akan dimulai dari pelaksanaan koordinasi antara pihak owner dengan para salesmen sehingga waktu bisa dilakukan dalam waktu yang sama dan tidak mengganggu proses waktu produk dan pemasaran offline. Pada tahap persiapan ini tim menyusun materi tentang manajemen produksi dan pemasaran digital.

b. Tahap pelaksanaan

Tahap pelaksanaan, akan dibagi menjadi beberapa kegiatan yang terdiri dari:

a) Pelatihan

Memberikan pelatihan manajemen produksi, terutama tentang pentingnya hasil produksi yang tahan lama di dalam kemasan.

b) Pemasaran dalam bentuk digital marketing. 


\section{HASIL dan LUARAN}

Pada pengabdian ini, kegiatan yang sudah terlaksana yaitu:

a. Kegiatan Pelatihan tentang Digital marketing dan Motivasi Usaha

Tim STIE Ekuitas memberikan pelatihan digital marketing dengan materi tentang:

1. Pemberian pemahaman tentang era digital dan disrupsi dalam industri makanan.

2. Teknik pembuatan digital marketing dengan membuat akun-akun komersial di media sosial seperti di Instagram dengan nama akun defyaazm. Dalam pelatihan ini termasuk tahap - tahap dalam proses memasarkan produk lewat media sosial tersebut. Pendalaman lebih dengan memberikan pemahaman basic triangle formula (Susanto, 2017).

3. Pembuatan Manual book atau modul untuk pembuatan digital marketing, untuk memasarkan dan melakukan promosi melalui internet, dan pendaftaran aplikasi Go-food di Gojek dan Grabfood di Grab. Materi dalam tentang bagaimana mencapai banjir order dari customer (Kenrianto, 2017).

4. Pemberian pemahaman beserta dengan pemberian motivasi kepada tim "Amalia" untuk meningkatkan pasarnya, melalui online dan offline sehingga terjadi peningkatan omzet penjualan. Sebagai dokumen diberikan modul pembuatan digital marketing. Didalamnya termasuk cara membuat content marketing untuk meningkatkan traffic dan menkonversinya menjadi penjualan (Santoso, 2017).

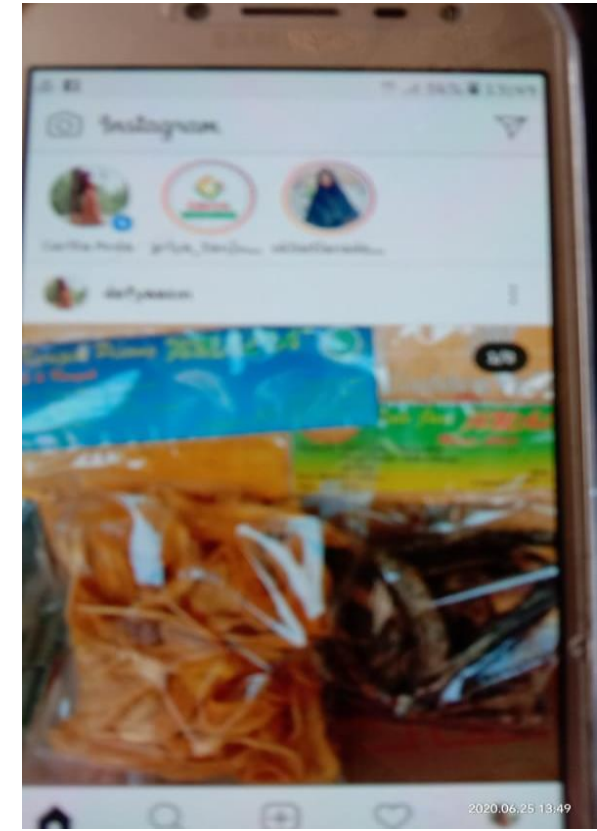

Gambar 2. Produk sale \& kripik pisang

"Amalia" teriklan di instagram

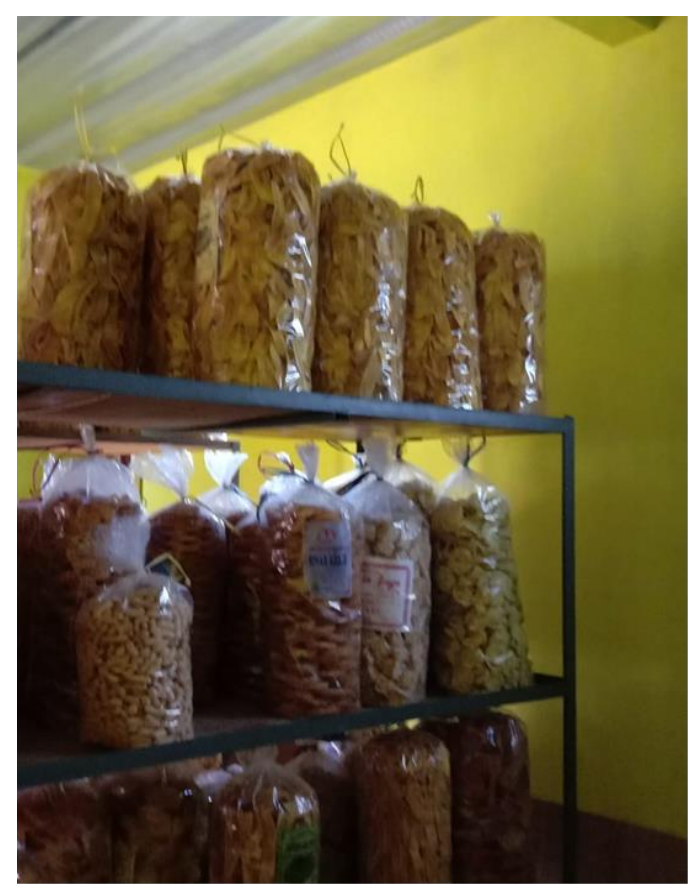

Gambar 3. Persediaan Produk sale \& kripik pisang "Amalia"

b. Kegiatan Pelatihan Peningkatan Kualitas Produksi dan Manajerial

Pemilik Usaha "Amalia" belum maksimal dalam proses produk. Oleh karena itu tim pengabdi Ekuitas memberikan solusi untuk mengatasi 
masalah tersebut dengan memberikan bantuan alat-alat produksi seperti :

a) Mesin spinner untuk meniriskan minyak setelah dilakukan penggorengan terhadap keripik.

b) Sealer untuk proses packaging dengan tujuan utama agar produk tahan lebih lama sehingga umur penjualannya juga lebih panjang serta kemasan produk terlihat lebih rapi dan menarik.

c) Pembuatan Manual book atau modul untuk analisis pengelolaan SDM termasuk tetapi tidak terbatas pada tentang organisasi, analisis jabatan, dan sistem penggajian.

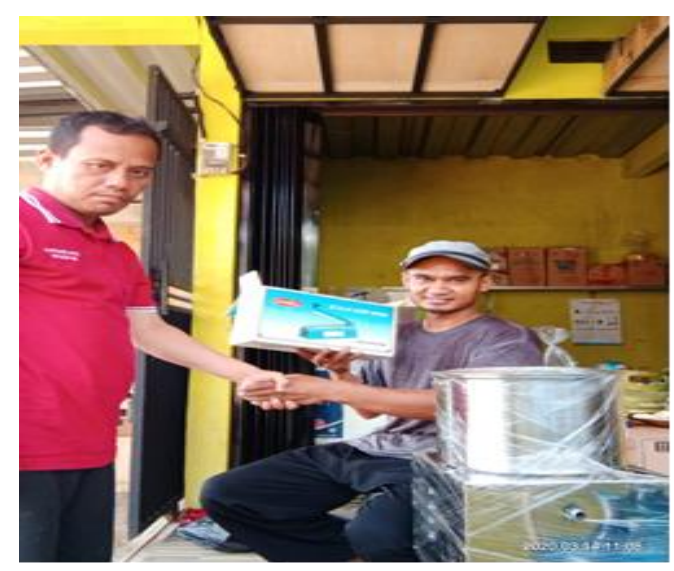

Gambar 3. Tim pengabdian menyerahkan ke dua alat produksi

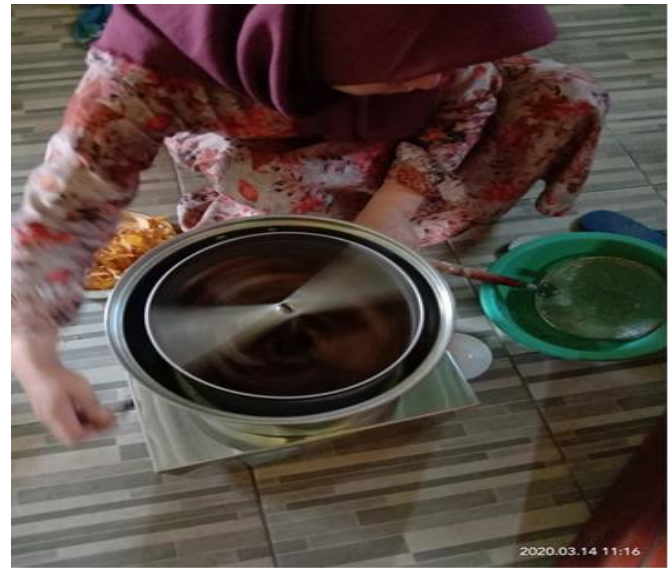

Gambar 4. Spinner dipergunakan sebagai peniris

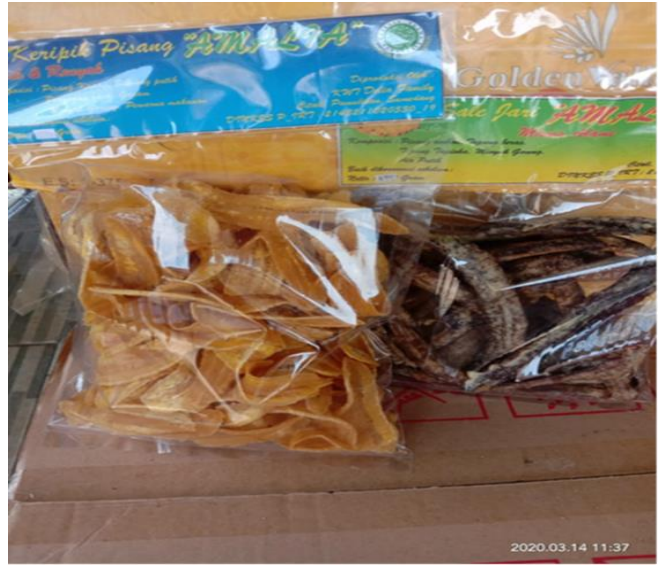

Gambar 5. Hasil produk sale \& kripik pisang siap dipasarkan

\section{Luaran Yang Dicapai}

Dari kegiatan yang sudah dilakukan pada pengabdian ini, beberapa capaian yang sudah dihasilkan antara lain :

1. Meningkatnya pemahaman dan keterampilan dalam mengelola produksi, pemasaran, dan Sumber Daya Manusia.

2. Meningkatnya pemahaman dan keterampilan pengemasan produk yang terstandardisasi dan menarik.

3. Meningkatnya pemahaman strategi pemasaran yang optimal di zaman digital seperti sekarang. Pemilik Sale dan Krimik "Amalia" sudah terampil dalam memasarkan produknya secara online seperti sudah terdaftar di aplikasi GoFood sehingga dapat meningkatkan omset di sekitar wilayah dan menjadi anggota komunitas Masyarakat Marketing Indonesia untuk pangsa pasar di Indonesia.

\section{KESIMPULAN DAN SARAN}

Kegiatan yang sudah dilakukan dalam program pengabdian kepada masyarakat ini memberikan dampak meningkatnya pemahaman pemilik dan manajemen Usaha Kripik dan Sale Pisang "Amalia" tentang perlunya peningkatan kualitas produk berupa efisiensi dalam proses penirisan 
produk sale dan kripik dari minyak setelah proses penggorengan serta kemasan / packaging yang berkualitas dalam meningkatkan lama periode expired date dan kemasana yang menarik.

Selain itu juga adanya peningkatan pemahaman dari pemilik dan manajemen Usaha Kripik dan Sale Pisang "Amalia" tentang tentang era digital dan disrupsi dalam industri makanan dan pentingnya serta urgensinya marketing digital dalam pemasaran produk makanan dalam rangka menaikkan omset usaha.

\section{DAFTAR PUSTAKA}

Santoso, D. (2018). Done is Better Than Perfect. Jakarta: PT Gramedia Pustaka Utama

Suryana, T. (2020). Buku UMKM: Petunjuk Teknis Wirausaha Naik Kelas, Diskuk Provinsi Jabar.

Susanto, GM (2017). The power of Digital marketing. Jakarta: PT Gramedia Pustaka Utama.

Murdjito, G. (2012). Modul Pelatihan Metodologi Pengabdian Masyarakat.

Kenrianto, I. (2017). Bisnis Online Revolution. Jakarta: PT Gramedia Pustaka Utama. 